\title{
SYNERGISTIC INTERACTION OF BRADYRHIZOBIUM AND ARBUSCULAR MYCORRHIZAL FUNGI WITH LEVELS OF MINERAL NITROGEN, PHOSPHORUS AND MOLYBDENUM ON PEANUT GROWN IN SANDY SOILS
}

\author{
Noha M. Abdelhameid \\ Soil Fertility and microbiology Dept., Desert Research Center (DRC), Egypt. \\ Corresponding author email: nmousa5@gmail.com
}

Received: Oct. 17,2018

Accepted: Oct. 28,2018

\begin{abstract}
A field experiment was conducted in the newly reclaimed sandy soils at ElBostan area, to investigate the influence of bio and mineral fertilizers on yield and yield components of peanut plants (Arachis hypogaea L.). Treatments include single or dual inoculation of Bradyrhizobium (BR) and the vesicular-arbuscular mycorrhizal fungi (VAM), as biofertilizers. In addition, eight mineral fertilizer treatments, nitrogen $(75,100$ and $120 \%$ of recommended dose), phosphorus (50, 75 and $100 \%$ of recommended dose) and two molybdenum treatments (with $200 \mathrm{~g} \mathrm{ha}^{-1}$ Mo as ammonium molybdate and without) under randomize complete block statistical design (RCBD). The results indicate that inoculation with $V A M+B R$ significantly increase hundred kernel weight, kernel, pods, hay and biological yield by $34.00,26.12,45.81,26.80$ and $34.32 \%$, respectively compared to uninoculated treatments followed by single treatments of BR then VAM. Data also revealed that bacterial-mycorrhizal-legume symbiosis increase significantly VAM infection and number of spores, nodule number and BR count, nitrogenase activity and alkali phosphatase compared with uninoculated. Also, the plant nitrogen, phosphorus and potassium (NPK) concentrations, protein content and shelling percentage were significantly increased due to dual biofertilizers followed by the single inoculation. Application of molybdenum increased nodules number per plant and BR count by 4.35 and $10.97 \%$ when compared with without molybdenum application. Generally, inoculation with VAM and BR can, synergistically, remove the deficient effect of $N$ and $P$ in the soil of low nutrient content. At the same time, increase the NUEs and PUEs. Bio-Dependency of pods, hay and biological yields increased significantly by 29.70, 36.89 and 45.87; 15.08, 21.02 and 26.93; and 20.76, 27.18 and $34.28 \%$, respectively with inoculation with VAM, BR and $V A M+B R$.
\end{abstract}

Key words: Mycorrhiza, Bradyrhizobium, Biofertilizers, peanut, sandy soils.

\section{INTRODUCTION}

Peanut (Arachis hypogaea L.) is considered one of the most important edible oil crops in Egypt, which is due to its seeds' high nutritive value for humans and the green leafy hay for feeding livestock, moreover to the seed oil's importance for industrial purposes. The main growing zones are sited in the north of the country; they include reclaimed desert to the east and west of the Nile Delta (Fageria et al., 1997). Peanut yields are known to be influenced by $\mathrm{N}$ uptake and $P$ mobilization. It is a crop ideally suited for studies on the tripartite association between legume, nitrogen fixing bacteria and mycorrhizal fungi (ElAzouni et al., 2008).

Arbuscular mycorrhizal

(AM) symbiosis that is formed by AM fungi and the roots of vascular plants is the most widespread mutualistic associations in environment (Willis et al., 2013; Chen et al., 2018). AM fungi play a very important role in ecosystems through nutrient 
cycling (Shokri and Maadi, 2009; Wu et al., 2011 and Tabassum et al., 2012). Mycorrhizae can also increase the availability and supply of slowly diffusing ions, such as phosphate to the plant (Sharda and Koide, 2010). In addition to their significant role in $P$ acquisition, $A M$ fungi can also provide other macro- and micro-nutrients such as $\mathrm{N}, \mathrm{K}, \mathrm{Mg}, \mathrm{Cu}$ and $\mathrm{Zn}$, particularly in soils where they are present in less soluble forms (Meding and Zasoski, 2008 and Smith and Read, 2008). In general, mycorrhizae stimulate plant growth not only by providing nutrients necessary for plant growth, but also help the plant to tolerate environmental stress (Kaya et al., 2009; Sheng et al., 2009 and Abiala et al., 2013). The formation of VAM symbiosis is considered to be one of the most promising strategies evolved by plants for handling nutrient-deficiency stresses. Although the role of $P$ nutrition in VAM associations has been a major attention of this field, an increasing number of studies have exposed that plants can also take up substantial amounts of $\mathbf{N}$ through the so-called mycorrhizal pathway (Bücking and Kafle, 2015).

One of the well-known $\mathrm{N}_{2}$-fixing plantmicroorganism interactions is the legume-rhizobia symbiosis, which is considered the most efficient and important process in crop production, so as to improve soil fertility and farming system flexibility (Mylona et al., 1995). Rhizobia (including Rhizobium, Bradyrhizobium, Mesorhizobium, Sinorhizobium) are generally regarded as microbial symbiotic partners of legumes and are mainly known for their role in the formation of nitrogen-fixing nodules (Antoun and Prévost, 2005). In particular, Rhizobium species are a vast group of soil borne rhizobia with representatives that have proven plant growth promoting activities through nitrogen fixation. These bacteria can equally produce plant growth regulators and solubilize organic and inorganic phosphates that would have a role in their plant growth promoting activities (Antoun et al., 1998).

The legume-nodulating rhizobia have the ability to reduce dinitrogen to ammonia and supply nitrogenous compounds to the plants. Thus, the plants gain independence of the existence of nitrogenous compounds in the soil environment (Mwenda et al., 2010).

Improved legume nutrition has been observed with AM fungi and Rhizobium (Guo et al., 2010; Tavasolee et al., 2011). The use of AMF gives promising results in legumes which can form tripartite symbiotic associations with noduleinducing rhizobia and AMF simultaneously, benefitting the plant by increasing both $P$ and $N$ use efficiency (Ossler et al., 2015; Chang et al., 2017).

A number of research articles shows the role of Bradyrhizobium and mycorrhizae alone and/or in combination in enhancing plant growth under stress conditions. However, in contrast, a few review papers are available which discuss the synergistic interactions between Bradyrhizobium and mycorrhizae for enhancing plant growth under normal or stressful environments. The present study comprehensively studies the effectiveness of Bradyrhizobium and mycorrhizal fungi for enhancing peanut yield and seed quality of peanut by biofertilizers include VA mycorrhizal fungi and Bradyrhizobium under different levels of nitrogen, phosphorus and molybdenum fertilizers.

\section{MATERIALS AND METHODS}

Summer season field experiment was conducted in the newly reclaimed sandy soils at El-Bostan area, Mohamed Reffat village (30o 12' $\mathrm{N}$ and $30 \circ 30^{\prime} \mathrm{E}, 7.4 \mathrm{~m}$ above sea level). The soil of the experimental site is coarse sand. 


\section{Experimental Design:}

This experiment was carried under fixed system sprinkler irrigation with spacing $18 \times 18 \mathrm{~m}$. The average precipitation rate was $9.78 \mathrm{~mm} \mathrm{hr}^{-1}$ and discharge of $3.17 \mathrm{~m} 3 \mathrm{hr}^{-1}$ for each sprinkler. The total experimental area was $30 \times 60 \mathrm{~m}\left(1800 \mathrm{~m}^{2}\right)$. The area was chiseled and harrowed. Then it was divided into 72 plots, the area of each experimental unit was $5 \times 5 \mathrm{~m}\left(25 \mathrm{~m}^{2}\right)$ with $0.5 \mathrm{~m}$ border between plots. The area was cultivated with peanut (Giza 5). Planting was carried out at 16 May 2016 by hand sowing; $0.5 \mathrm{~m}$ apart between rows, $0.2 \mathrm{~m}$ between plants in the row and two seeds in each site. The randomize complete block statistical design (RCBD) was carried out with four biofertilizers (Bradyrhizobium (BR), Vascular Arbuscular Mycorrhiza Fungi (VAM), $B R+V A M$ and without). In addition, eight mineral fertilizer treatments, three $\mathrm{N}$ levels [80.5 (75\%), $107.0(100 \%)$ and $128.5(120 \%)$ $\mathrm{kg} \mathrm{N} \mathrm{ha}^{-1}$ as ammonium nitrate $(33.5 \% \mathrm{~N})$, three $P$ levels $[35.7$ (50\%), 53.6 (75\%) and $71.4(100 \%) \mathrm{kg} \mathrm{P}_{2} \mathrm{O}_{5} \mathrm{ha}^{-1}$ as mono calcium superphosphate $\left.\left(15.5 \% \mathrm{P}_{2} \mathrm{O}_{5}\right)\right]$. Nitrogen and phosphorus fertilizers were split into three equal doses. Two molybdenum treatments (200 $\mathrm{g} \mathrm{ha}^{-1}$ Mo as ammonium molybdate and without). All treatments received $57.1 \mathrm{~kg} \mathrm{~K}_{2} \mathrm{O} \mathrm{ha}^{-1}$. At harvesting, peanut plants of each experimental unit were taken separately to determine peanut yield and yield components. Then soil samples were taken separately from each experimental unit at soil depth of 0 30 and $30-60 \mathrm{~cm}$.

\section{Soil Analyses:}

Soil paste extracts were obtained according to (Page et al., 1982). Main soil chemical and nutritional characteristics are presented in Table (1). Soluble cations and anions, $\mathrm{pH}$ and EC were also measured. Total calcium carbonate content $\left(\mathrm{CaCO}_{3} \%\right)$ was determined using the pressure Calcimeter method (Page et al., 1982). Organic carbon content (OC\%) was determined using Walkely and Black method (Nelson and Sommers, 1982). Available potassium was extracted by ammonium acetate extraction and analyzed using Flame Photometer apparatus (Knudsen et al., 1982). Total-N was measured using Kjeldahl. Available phosphorus was extracted by ammonium bicarbonate and measured colorimetric using spectrophotometer (Olsen and Sommers, 1982). Particle size distribution of the soil samples was carried out using hydrometer method (Gee and Bauder, 1986).

Table (1): Mean soil physical, chemical and nutritional characteristics at the experimental site.

\begin{tabular}{|c|c|c|c|c|c|c|c|c|c|c|c|c|c|c|c|}
\hline \multirow{3}{*}{$\begin{array}{l}\text { Depth } \\
\text { (cm) }\end{array}$} & \multicolumn{3}{|c|}{$\begin{array}{c}\text { Particle size } \\
\text { distribution (\%) }\end{array}$} & \multirow{3}{*}{ Texture } & \multirow{3}{*}{$\mathrm{pH}^{*}$} & \multirow{3}{*}{$\begin{array}{l}\text { E.C ** } \\
\text { dSm-1 }\end{array}$} & \multirow{3}{*}{$\begin{array}{c}\mathrm{CaCO}_{3} \\
\%\end{array}$} & \multicolumn{8}{|c|}{ Chemical analysis } \\
\hline & \multirow[t]{2}{*}{ Sand } & \multirow[t]{2}{*}{ Silt } & \multirow[t]{2}{*}{ Clay } & & & & & \multicolumn{4}{|c|}{$\begin{array}{c}\text { Soluble cations } \\
\text { (meq/l) }\end{array}$} & \multicolumn{4}{|c|}{$\begin{array}{c}\text { Soluble anions } \\
\text { (meq/l) }\end{array}$} \\
\hline & & & & & & & & $\mathrm{Na}^{+}$ & $\mathrm{Ca}^{++}$ & $\mathrm{Mg}^{++}$ & $\mathrm{K}^{+}$ & $\mathrm{CO}_{3}{ }^{-}$ & $\mathrm{HCO}_{3}$ & $\mathrm{Cl}^{-}$ & $\mathrm{SO}_{4}^{--}$ \\
\hline $0-30$ & 96.1 & 1.5 & 2.4 & Sand & 8.05 & 1.46 & 7.0 & 5.1 & 5.5 & 3.5 & 0.7 & -- & 5.6 & 6.0 & 3.2 \\
\hline $30-60$ & 94.5 & 1.2 & 4.3 & Sand & 8.13 & 1.36 & 5.7 & 6.2 & 4.5 & 3.0 & 0.7 & -- & 5.1 & 6.5 & 2.8 \\
\hline \multicolumn{16}{|c|}{ Available nutrients $\mathrm{mg} / \mathrm{kg}$} \\
\hline $\begin{array}{l}\text { Depth } \\
\text { (cm) }\end{array}$ & \multicolumn{3}{|c|}{$\mathbf{N}$} & \multicolumn{2}{|l|}{$\mathbf{P}$} & $\mathbf{K}$ & Zn & \multicolumn{2}{|c|}{ Mn } & \multicolumn{2}{|c|}{$\mathrm{Fe}$} & \multicolumn{2}{|c|}{$\mathrm{Cu}$} & \multicolumn{2}{|c|}{ Mo } \\
\hline $0-30$ & \multicolumn{3}{|c|}{106.5} & \multicolumn{2}{|l|}{7.2} & 61.6 & 0.84 & \multicolumn{2}{|c|}{1.78} & \multicolumn{2}{|c|}{4.35} & \multicolumn{2}{|c|}{0.04} & \multicolumn{2}{|c|}{0.02} \\
\hline $30-60$ & \multicolumn{2}{|c|}{107.5} & & \multicolumn{2}{|l|}{5.8} & 102.5 & 0.72 & \multicolumn{2}{|c|}{1.49} & \multicolumn{2}{|c|}{4.12} & \multicolumn{2}{|c|}{0.03} & \multicolumn{2}{|c|}{0.02} \\
\hline
\end{tabular}

*(1:2.5) soil : water suspension

** Soil paste extract 


\section{Bio-Analyses:}

Rhizosphere soil sample were collected at harvest and analyzed for number of AM spores and Bradyrhizobium count.

Assessment of VA-mycorrhizal infection was measured on composite samples of three plants per plot: The staining method of Phillips and Hayman (1970) was used for preparing root samples for microscopic observation. The gridlines intersect method of Giovannetti and Mosse (1980) was used to estimate the VA-mycorrhizal infection percentage.

Mycorrhizal Colonization (\%)

$=\frac{\text { Total number of root segments colonized }}{\text { Total Number of root segments studied }} \times 100$

Nitrogenase activity was determined on a detached root system, using gas chromatograph (Thermo Scientific TRACE GC Ultra equipped with FID detector and Capillary column CPPoraBOND Ufused silica plot $25 \mathrm{~m} \times \mathbf{0 . 3 2}$ $\mathrm{mm}, \mathrm{df}=7 \_\mathrm{m}$ ) as described by (Abd-Alla, 2011). For determination of phosphatase activity disodium phenylphosphate served as enzyme substrate (Öhlinger, 1996).

Bio dependency (BD) is the increase of yield or yield components which refer to the bio-inoculation and calculate as:

$$
\begin{aligned}
& \text { Yield Bio - Dependency }(\%) \\
& =\frac{\text { Yield }(\text { Inoculated })-\text { Yield }(\text { UnInoculated })}{\text { Yield }(\text { UnInoculated })} \times 100
\end{aligned}
$$

\section{Plant analysis:}

Plant samples were taken at harvesting from each treatment, dried at $70^{\circ}$, and ground for the determination of $\mathrm{N}, \mathrm{P}, \mathrm{K}$. The samples were digested using $\mathrm{H}_{2} \mathrm{SO}_{4}$ and $\mathrm{H}_{2} \mathrm{O}_{2}$ for determination of phosphorus and potassium content. Total phosphorus content in the extract was determined using Vanado-Molybdate yellow color method as described by (Jackson, 1970). Total potassium content was determined using Flame photometer according to (Cottenie et al., 1982). Total nitrogen was determined using the micro kjeldahl method (Bremner and Mulvaney, 1982). Protein content of seeds and hay were determined by multiplying total $\mathrm{N}$ by the standard factor 6.25 (Hunter, 1984).

\section{Yield and yield components:}

At harvest, one square meter from each plot was taken to determine kernel, pods, hay and biological yields ( $\mathrm{kg} \mathrm{ha}^{-1}$ ). Shelling percentage was calculated as:

Selling Percentage (\%)

$=\frac{(\text { Weight of kernels } / \text { plant })}{(\text { Weight of Pods } / \text { plant })} \times 100$

\section{Statistical analyses:}

The obtained data were carried out using COSTAT Software Ver. 6.4. Analysis of Variance (ANOVA) was used to test pods, kernel, hay and biomass production of Peanut. Differences in mean values of various treatments were evaluated by Duncan's multiple range test as described in (Gomez et al., 1984).

Nitrogen Efficiency Analysis:

Analysis of the nitrogen fertilizer efficiencies was carried out using the efficiency parameters defined by Huggins and Pan (2003) as follows:

$$
\begin{aligned}
& \text { Nitrogen use efficiency }(N U E)=G_{w} / N_{s} \\
& \text { Nitrogen utilization efficiency }(N U T E)=G_{w} / N_{t} \\
& \text { Grain } N \text { accumulation efficiency }(G N A E)=N_{g} / N_{s} \\
& \text { Where } \\
& \left(G_{w}\right) \text { Grain yield } \\
& \left(N_{g}\right) \text { Grain nitrogen } \\
& \left(N_{s}\right) \text { Nitrogen supply } \\
& \left(N_{t}\right) \text { Aboveground plant nitrogen }
\end{aligned}
$$

Phosphorus Efficiency Analysis:

Analysis of the Phosphorus fertilizer efficiencies was carried out using the efficiency parameters defined by Huggins and Pan (2003) as follows:

\footnotetext{
Phosphorus use efficiency $(P U E)=G_{w} / P_{s}$

Phosphorus utilization efficiency $(P U T E)=G_{w} / P_{t}$

Grain $P$ accumulation efficiency $(G P A E)=P_{g} / P_{s}$
} 
Where:

$\left(G_{w}\right)$ Grain yield

$\left(P_{g}\right)$ Grain Phosphorus

$\left(P_{s}\right)$ Phosphorus supply

$\left(P_{t}\right)$ Aboveground plant Phosphorus

\section{RESULTS AND DISCUSSION}

Root colonization and number of spores in soil rhizosphere:

Data in Table 2 illustrated the root colonization and number of spores. It is very interesting to observe that the biofertilizers significantly increased mycorrhizal infection from $16.55 \%$ in uninoculated to 53.13 and $55.07 \%$ and from 9.01 in uninoculated to 13.87 and 13.95 spores/g soil for VAM and VAM+BR treatments, respectively. Root colonization and number of colonizations were enhanced significantly by the influence of VAM in presence of Bradyrhizobium compared to VAM or uninoculated treatments separately. At the same time, the highest mycorrhizal infection and number of spores/g under mineral fertilizers treatments were observed in $\mathrm{P} 1$ treatment $(39.87 \%$ and 11.67 spores/g soil) followed significantly by $\mathrm{P} 2$ treatment $(37.52 \%$ and 11.60 spores/g soil), while the lowest percentage was observed in N1 (34.19\%) for root colonization and N3 (11.3 spores/g soil) for number of spores. The influence of VAM in presence of Bradyrhizobium was more effective by applying 50 and $75 \%$ of $P$ fertilizer recommended dose. (Kobae et al., 2016) established that high phosphorus supply exerts strong inhibitory effect on AM colonization. $\mathbf{N}$ starvation may be able to trigger a signal that counteracts the inhibition of high $P$ availabilities on AM colonization (Nouri et al., 2014; BreuillinSessoms et al., 2015). This result is in agreement with ARM (2014), root colonization (percent) was enhanced significantly by the influence of VAM in presence of Rhizobium compared to in absence of any one. Solaiman et al. (2005) also recorded enhanced root colonization in chickpea due to the influence of VAM and Rhizobium. Similar results showed by (Khanam et al., 2005).

\section{Number of nodules and Bradyrhizobium count:}

The influence of different combinations of VAM, BR and mineral fertilizers on number of nodules per plant and BR count per $g$ soil is exhibited in Table 2. Nodulation of the roots of peanut plants was significantly increased and improved with the application of Bradyrhizobium either singly or combined with VAM under the mineral fertilizer treatments comparing with the uninoculated treatments. The maximum number of nodules (363.37/plant) and BR count (58.22 x 104 cfu/g soil) were observed with interaction of VAM and BR. The individual of $B R$ treatment significantly followed the mixed treatment and has the second highest number of nodules (332.52 I plant). The maximum number of nodules and BR count were observed under mineral treatment N1 ( $75 \%$ of $\mathrm{N}$ recommended dose). At the same time, Application of Mo increased nodules number per plant and BR count by 4.35 and $10.97 \%$ when compared with without Mo application. (Bulgarelli et al., 2017) stated that VAM promoted plant biomass and nodule formation compared to non-VAM plants. At the same time, Roots of inoculated soybean plants were highly colonized, with high abundance of arbuscules. Also, Mirdhe and Lakshman (2009) found that Mycorrhizal fungi and Rhizobium were found to be synergistic with respect to nitrogen fixation and per cent of root colonization. 
Table (2): Effect of biological and mineral fertilizers on VAM infection and count, nodules number, Bradyrhizobium count, Nitrogenase and Alkali phosphatase

\begin{tabular}{|c|c|c|c|c|c|c|c|}
\hline \multicolumn{2}{|c|}{ Fertilizers } & \multirow{2}{*}{$\begin{array}{c}\text { VAM } \\
\text { infection } \\
(\%)\end{array}$} & \multirow{2}{*}{$\begin{array}{l}\text { VAM } \\
\text { count } \\
\text { Ig soil }\end{array}$} & \multirow{2}{*}{$\begin{array}{c}\text { nodule } \\
\text { numberl } \\
\text { plant }\end{array}$} & \multirow{2}{*}{$\begin{array}{l}\text { Bradyrhizobium } \\
\text { count } 10^{4} \text { cfu g }^{-1} \\
\text { soil }\end{array}$} & \multirow{2}{*}{$\begin{array}{c}\text { Nitrogenase } \\
\text { activity } \\
\left(\text { nmol } \mathrm{C}_{2} \mathrm{H}_{5}\right. \\
\left.\mathrm{g}^{-1} \text { plant } \mathrm{h}^{-1}\right)\end{array}$} & \multirow{2}{*}{$\begin{array}{c}\text { Alkali } \\
\text { phosphatase } \\
\text { (mg phenol } \\
\left.\mathrm{g}^{-1} \mathrm{hr}^{-1}\right) \\
\end{array}$} \\
\hline Mineral & Bio & & & & & & \\
\hline \multirow{5}{*}{ N1 } & Un-Inoc. & 16.1 & 8.9 & 91 & 22.4 & 31.4 & \begin{tabular}{|l|}
36.1 \\
\end{tabular} \\
\hline & VAM & 52.1 & 13.7 & 278 & 23.5 & 67.6 & 43.8 \\
\hline & BR & 18.3 & 9.0 & 354 & 85.2 & 79.4 & 37.2 \\
\hline & VAM+BR & 50.1 & 13.8 & 420 & 88.4 & 84.8 & 44.9 \\
\hline & Mean & 34.2 & 11.4 & 285.8 & 54.9 & 65.8 & 40.5 \\
\hline \multirow{5}{*}{ N2 } & Un-Inoc. & 17.3 & 9.1 & 95 & 20.8 & 30.4 & 37.2 \\
\hline & VAM & 51.1 & 13.6 & 287 & 21.6 & 65.7 & 43.5 \\
\hline & BR & 20.4 & 8.9 & 341 & 73.5 & 75.4 & 37.5 \\
\hline & VAM+BR & 52.1 & 13.7 & 418 & 74.3 & 82.7 & 44.1 \\
\hline & Mean & 35.2 & 11.3 & 285.3 & 47.6 & 63.6 & 40.6 \\
\hline \multirow{5}{*}{ N3 } & Un-Inoc. & 17.9 & 9.0 & 97 & 18.4 & 31.1 & 36.2 \\
\hline & VAM & 53.1 & 13.5 & 294 & 19.2 & 62.1 & 43.4 \\
\hline & BR & 19.2 & 9.1 & 335 & 51.4 & 70.4 & 37.9 \\
\hline & VAM+BR & 54.8 & 13.6 & 410 & 52.6 & 78.8 & 43.8 \\
\hline & Mean & 36.3 & 11.3 & 284.0 & 35.4 & 60.6 & 40.3 \\
\hline \multicolumn{2}{|c|}{ Mean } & 35.2 & 11.3 & 285.0 & 45.9 & 63.3 & 40.5 \\
\hline \multirow{5}{*}{ P1 } & Un-Inoc. & 15.2 & 9.1 & 98 & 18.7 & 30.7 & 40.0 \\
\hline & VAM & 62.1 & 14.2 & 251 & 19.1 & 57.6 & 50.5 \\
\hline & BR & 17.9 & 9.2 & 297 & 49.7 & 63.4 & 39.5 \\
\hline & VAM+BR & 64.3 & 14.2 & 310 & 50.8 & 64.1 & 51.2 \\
\hline & Mean & 39.9 & 11.7 & 239.0 & 34.6 & 54.0 & 45.3 \\
\hline \multirow{5}{*}{ P2 } & Un-Inoc. & 16.4 & 9.0 & 104 & 17.4 & 29.5 & 38.2 \\
\hline & VAM & 55.8 & 14.1 & 285 & 18.0 & 56.1 & 48.5 \\
\hline & BR & 19.1 & 9.1 & 311 & 47.4 & 62.4 & 37.5 \\
\hline & VAM+BR & 58.8 & 14.2 & 320 & 48.7 & 63.7 & 48.8 \\
\hline & Mean & 37.5 & 11.6 & 255.0 & 32.9 & 52.9 & 43.3 \\
\hline \multirow{5}{*}{ P3 } & Un-Inoc. & 17.9 & 8.9 & 110 & 17.8 & 29.9 & 35.2 \\
\hline & VAM & 50.1 & 14.0 & 295 & 18.7 & 55.7 & 44.4 \\
\hline & BR & 17.3 & 9.1 & 315 & 49.0 & 61.8 & 33.1 \\
\hline & VAM+BR & 54.8 & 14.1 & 332 & 49.7 & 61.9 & 43.8 \\
\hline & Mean & 35.0 & 11.5 & 263.0 & 33.8 & 52.3 & 39.1 \\
\hline \multicolumn{2}{|c|}{ Mean } & 37.5 & 11.6 & 252.3 & 33.8 & 53.1 & 42.6 \\
\hline \multirow{5}{*}{$\begin{array}{c}\text { Without } \\
\text { Mo }\end{array}$} & Un-Inoc. & 15.5 & 9.0 & 93 & 19.1 & 29.3 & 35.4 \\
\hline & VAM & 48.7 & 13.8 & 281 & 20.1 & 45.6 & 38.9 \\
\hline & \begin{tabular}{|l|} 
BR \\
\end{tabular} & 25.2 & 9.2 & 345 & 47.2 & 58.4 & 36.9 \\
\hline & VAM+BR & 52.1 & 13.9 & 338 & 48.4 & 61.5 & 39.1 \\
\hline & Mean & 35.4 & 11.5 & 264.3 & 33.7 & 48.7 & 37.6 \\
\hline \multirow{5}{*}{$\begin{array}{l}\text { With } \\
\text { Mo }\end{array}$} & Un-Inoc. & 16.1 & 9.1 & 101 & 24.1 & 33.5 & 36.7 \\
\hline & VAM & 52.1 & 14.1 & 284 & 20.0 & 48.2 & 39.8 \\
\hline & BR & 24.3 & 9.4 & 359 & 52.4 & 61.2 & 38.7 \\
\hline & VAM+BR & 53.6 & 14.1 & 359 & 52.9 & 62.4 & 40.2 \\
\hline & \begin{tabular}{|l|} 
Mean \\
\end{tabular} & 36.5 & 11.7 & 275.8 & 37.4 & 51.3 & 38.9 \\
\hline \multicolumn{2}{|c|}{ Mean } & 36.0 & 11.6 & 270.0 & 35.5 & 50.0 & 38.2 \\
\hline \multirow[t]{2}{*}{$\operatorname{LSD}_{0.05}$} & Mineral & 0.107 & 0.037 & 1.152 & 0.247 & 0.251 & 0.141 \\
\hline & Bio & 0.076 & 0.026 & 0.814 & 0.174 & 0.178 & 0.1 \\
\hline
\end{tabular}


Nodule Activity:

Specific nitrogenase (acetylenereduction) activity per gram fresh weight nodule was significantly increased by mixed inoculation with VAM+BR $(65.97$ nmol C2H5 g-1 plant $h-1)$ followed by BR (66.63 nmol C2H5 g-1 plant h-1) (Table 2). Mixed inoculation treatment with $\mathrm{N} 1$ mineral fertilizer recorded the highest nitrogenase activity (84.8 $\mathrm{nmol}$ C2H5 g-1 plant $h-1)$. While under mixed inoculation treatment and without-Mo record the lowest nitrogenase activity $(61.5 \mathrm{nmol}$ C2H5 g-1 plant h-1). Table (2) also showed that phosphatase activity recorded significant increase due to mixed inoculation treatments. Mixed inoculation treatment with P1 treatment recorded the highest phosphatase activity $(51.2 \mathrm{mg}$ phenol g-1 hr-1) followed by VAM under P2 treatments (50.5 mg phenol g-1 hr-1). Bulgarelli et al. (2017) found that VAM symbiosis increased nitrogenase activity, $\mathrm{P}$ content in nodules and leaf $\mathrm{N}$ content and reduced the metabolic limitation of photosynthesis under $P$ starvation, which indicated the VAM stimulus to symbiotic N2 fixation and photosynthesis. Then mycorrhizal symbiosis could not completely meet soybean $P$ demand compared with well-nourished soybean plants, which produced higher nodules biomass. Badawi et al. (2011) stated that bacterization of peanut seeds with bradyrhizobia utilized considerable improvement in number and mass of root nodules, increased the rate of acetylene reduction and all growth characters in compared to comparison to the uninoculated.

Yield and yield components (pods, seeds, hay, 100 seeds):

Data in Table 3 indicated that the yield parameters (100 kernel weight, kernel, pods, hay and biological yield) increased significantly with inoculation with VAM+BR, BR and VAM under all mineral fertilizer treatments when compared with uninoculated treatments. In other words, N2 -fixation process and $P$ solubility maximizes the yield of inoculated plants as compared with uninoculated treatments. Inoculation with VAM+BR significantly increase hundred kernel weight, kernel, pods, hay and biological yield by $34.00,26.12,45.81,26.80$ and $34.32 \%$, respectively compared to uninoculated treatments.

The beneficial effect of interaction between VAM and Bradyrhizobium, in general, greatly increase yield parameters of inoculated plants as compared with the uninoculated ones. This indicated that $N$ and $P$ supply was influenced by VAM and by bradyrhizobium inoculation. The data also cleared that the yield parameters increased in Mo treated plants when compared to untreated ones.

This increase refers to the role of Mo to enhances the N2 fixation efficiency in bradyrhizobium nodules. Jackson and Mason (1984) found positive relationships among $P$ availability, VA mycorrhizal infection and pod yield in groundnut (Arachis hypogaea L.). Alloush et al. (2000) found that chickpea plants inoculated with mycorrhizal fungus had higher number of nodules, shoot phosphorus content, shoot dry weight and grain yield than uninoculated chickpea plants.

Further grain yield was harvested with the inoculation of both Bradyrhizobium and VA mycorrhizal fungi in both $P$ amended soils. El-Azouni et al. (2008) reported that the biomass and grain yield were significantly improved by using the dual bio-preparations of AM fungi with Bradyrhizobium. Significantly maximum shelling percentage (64.46\%) was obtained in VAM+BR combination treatment followed by BR treatment $(60.66 \%)$ when compared to uninoculated treatment. The present results in 
agreement with the findings of (Malligawad, 2010) which found that application of Rhizobium and trichoderma increases shelling percent in groundnut. Also, Zalate and Padmani, 2009 and Mahrous et al., 2015) finding the same.

Table (3): Grain, Pod, Hay yields of peanut plants, inoculated with VAmycorrhizal Fungi and lor Bradyrhizobium, grown in soil amended with either nitrogen, phosphorus or molybdenum fertilizers.

\begin{tabular}{|c|c|c|c|c|c|c|c|c|c|c|c|}
\hline \multicolumn{2}{|c|}{ Fertilizers } & \multirow{2}{*}{$\begin{array}{c}100 \\
\text { Kernel } \\
\text { weight } \\
\text { (g) }\end{array}$} & \multirow{2}{*}{$\begin{array}{c}\text { Kernel } \\
\text { yield (kg } \\
\left.\text { ha }^{-1}\right)\end{array}$} & \multirow{2}{*}{$\mid \begin{array}{c}\text { Pods yield } \\
\left(\mathrm{kg} \mathrm{ha}^{-1}\right)\end{array}$} & \multirow{2}{*}{$\begin{array}{c}\text { Hay yield } \\
\left(\mathrm{kg} \mathrm{ha}^{-1}\right)\end{array}$} & \multirow{2}{*}{$\mid \begin{array}{c}\text { Biological } \\
\text { yield (kg } \\
\left.\text { ha }^{-1}\right)\end{array}$} & \multirow{2}{*}{\begin{tabular}{|c|} 
Shelling \\
percenta \\
ge (\%)
\end{tabular}} & \multirow{2}{*}{\begin{tabular}{|c|}
$\begin{array}{c}\text { Kernel } \\
\text { yield } \\
\text { B.D.* } \\
\text { (\%) }\end{array}$ \\
\end{tabular}} & \multirow{2}{*}{\begin{tabular}{|c|}
$\begin{array}{c}\text { Pods } \\
\text { yield } \\
\text { B.D.* } \\
\text { (\%) }\end{array}$ \\
\end{tabular}} & \multirow{2}{*}{$\begin{array}{l}\text { Hay yield } \\
\text { B.D.* (\%) }\end{array}$} & \multirow{2}{*}{$\begin{array}{l}\text { Biological } \\
\text { yield B.D.* } \\
\text { (\%) }\end{array}$} \\
\hline Mineral & Bio & & & & & & & & & & \\
\hline \multirow{5}{*}{ N1 } & Un-Inoc. & 68.1 & 1411 & 2235 & 3179 & 5414 & 58.84 & \begin{tabular}{|c|}
$-\cdots-\cdot$ \\
\end{tabular} & ----- & ----- & ----- \\
\hline & VAM & 80.8 & 1694 & 2692 & 3808 & 6500 & 60.07 & 20.06 & 20.45 & 19.79 & 20.06 \\
\hline & $\overline{B R}$ & 86.7 & 1688 & 2810 & 3999 & 6809 & 62.93 & 19.63 & 25.73 & 25.79 & 25.77 \\
\hline & VAM+BR & 91.0 & 1717 & 2918 & 4186 & 7104 & 63.13 & 21.69 & 30.56 & 31.68 & 31.22 \\
\hline & Mean & 81.6 & 1628 & 2664 & 3793 & 6457 & 61.2 & 20.5 & 25.6 & 25.8 & 25.7 \\
\hline \multirow{5}{*}{ N2 } & Un-Inoc. & 68.9 & 1426 & 2246 & 3411 & 5657 & 53.68 & ----- & ---- & ----- & ----- \\
\hline & VAM & 82.5 & 1775 & 3077 & 3906 & 6983 & 56.04 & 24.47 & 37.00 & 14.51 & 23.44 \\
\hline & BR & 88.4 & 1796 & 3205 & 4155 & 7360 & 57.69 & 25.95 & 42.70 & 21.81 & 30.10 \\
\hline & VAM+BR & 92.7 & 1810 & 3372 & 4309 & 7681 & 63.49 & 26.93 & 50.13 & 26.33 & 35.78 \\
\hline & Mean & 83.1 & 1702 & 2975 & 3945 & 6920 & 57.7 & 25.8 & 43.3 & 20.9 & 29.8 \\
\hline \multirow{5}{*}{ N3 } & Un-Inoc. & 71.4 & 1471 & 2367 & 3572 & 5939 & 54.34 & ----- & ב--- & ---- & ---- \\
\hline & VAM & 83.3 & 1771 & 3060 & 4002 & 7062 & 57.26 & 20.39 & 29.28 & 12.04 & 18.91 \\
\hline & BR & 91.0 & 1825 & 3187 & 4232 & 7419 & 57.88 & 24.07 & 34.64 & 18.48 & 24.92 \\
\hline & VAM+BR & 93.5 & 1870 & 3441 & 4407 & 7848 & 62.15 & 27.12 & 45.37 & 23.38 & 32.14 \\
\hline & Mean & 84.8 & 1734 & 3014 & 4053 & 7067 & 57.9 & 23.9 & 36.4 & 18.0 & 25.3 \\
\hline \multicolumn{2}{|c|}{ Mean } & 83.2 & 1688 & 2884 & 3931 & 6815 & 59.0 & 59.0 & 35.1 & 21.5 & 26.9 \\
\hline \multirow{5}{*}{ P1 } & Un-Inoc. & 64.6 & 1409 & 2157 & 3218 & 5375 & 60.50 & ----- & ---- & ---- & ----- \\
\hline & VAM & 89.3 & 1762 & 2635 & 3727 & 362 & 64.59 & 25.05 & 22.16 & 15.82 & 18.36 \\
\hline & BR & 85.9 & 1751 & 2711 & 3892 & 6603 & 66.87 & 24.27 & 25.68 & 20.94 & 22.85 \\
\hline & VAM+BR & 91.0 & 1777 & 2937 & 4094 & 7031 & 65.32 & 26.12 & 36.16 & 27.22 & 30.81 \\
\hline & Mean & 82.7 & 75 & 2610 & 3733 & 43 & 64.3 & 25.1 & 28.0 & 21.3 & 24.0 \\
\hline \multirow{5}{*}{ P2 } & Un-Inoc. & 69.7 & 1433 & 2100 & 3405 & 5505 & 55.34 & ---- & ---- & ---- & ---- \\
\hline & VAM & 91.0 & 1784 & 3036 & 3858 & 6894 & 56.48 & 24.49 & 44.57 & 13.30 & 25.23 \\
\hline & BR & 86.7 & 1761 & 3118 & 4053 & 7171 & 58.76 & 22.89 & 48.48 & 19.03 & 30.26 \\
\hline & VAM+BR & 93.5 & 1856 & 3354 & 4290 & 7644 & 68.24 & 29.52 & 59.71 & 25.99 & 38.86 \\
\hline & Mean & 85.2 & 1709 & 2902 & 3902 & 6804 & 59.7 & 25.6 & 50.9 & 19.4 & 31.5 \\
\hline \multirow{5}{*}{ P3 } & Un-Inoc. & 72.3 & 1430 & 2231 & 3533 & 5764 & 54.10 & ----- & ---- & ---- & ----- \\
\hline & VAM & 92.7 & 1814 & 3068 & 4007 & 7075 & 55.10 & 26.85 & 37.52 & 13.42 & 22.74 \\
\hline & BR & 87.6 & 1761 & 3196 & 4156 & 7352 & 59.13 & 23.15 & 43.25 & 17.63 & 27.55 \\
\hline & VAM+BR & 94.4 & 1873 & 3462 & 4446 & 7908 & 64.10 & 30.98 & 55.18 & 25.84 & 37.20 \\
\hline & Mean & 86.7 & 1720 & 2989 & 4036 & 7025 & 58.1 & 27.0 & 45.3 & 19.0 & 29.2 \\
\hline \multicolumn{2}{|c|}{ Mean } & 84.9 & 1701 & 2834 & 3890 & 6724 & 60.7 & 60.7 & 41.4 & 19.9 & 28.2 \\
\hline \multirow{5}{*}{$\begin{array}{c}\text { without } \\
\text { Mo }\end{array}$} & Un-Inoc. & 66.4 & 1400 & 2179 & 3179 & 5358 & 58.51 & ---- & ---- & $\begin{array}{l}---- \\
\end{array}$ & ----- \\
\hline & VAM & 79.6 & 1584 & 2510 & 3808 & 6318 & 57.78 & 13.14 & 15.19 & 19.79 & 17.92 \\
\hline & BR & 85.7 & 1608 & 2783 & 3999 & 6782 & 63.11 & 14.86 & 27.72 & 25.79 & 26.58 \\
\hline & VAM+BR & 91.0 & 1692 & 2892 & 4186 & 7078 & 64.25 & 20.86 & 32.72 & 31.68 & 32.10 \\
\hline & Mean & 80.7 & 1571 & 2591 & 3793 & 6384 & 60.9 & 16.3 & 25.2 & 25.8 & 25.5 \\
\hline & Un-Inoc. & 70.2 & 1425 & 2190 & 3572 & 5762 & 52.19 & ---- & ---- & ----- & ---- \\
\hline & VAM & 82.4 & 1698 & 2879 & 4002 & 6881 & 55.66 & 19.16 & 31.46 & 12.04 & 19.42 \\
\hline with Mo & BR & 90.4 & 1789 & 3214 & 4232 & 7446 & 58.98 & 25.54 & 46.76 & \begin{tabular}{|l|}
18.48 \\
\end{tabular} & 29.23 \\
\hline & VAM+BR & 92.3 & 1796 & 3441 & 4407 & 7848 & 65.07 & 26.04 & 57.12 & 23.38 & 36.20 \\
\hline & Mean & 83.8 & 1677 & 2931 & 4053 & 6984 & 58.00 & 23.6 & 45.1 & 18.0 & 28.3 \\
\hline & ean & 83.1 & 1650 & 2785 & 3912 & 6697 & 59.90 & 59.90 & 37.2 & 21.2 & 27.3 \\
\hline $\operatorname{LSD}_{0.05}$ & Mineral & 0.30 & 6.0 & 10.2 & 14.3 & 24.5 & 0.21 & 0.07 & 0.10 & 0.08 & 0.08 \\
\hline & Bio & 0.21 & 4.3 & 7.2 & 10.1 & 17.3 & 0.15 & 0.05 & 0.07 & 0.05 & 0.06 \\
\hline
\end{tabular}

*Bio Dependency 
Bio-Dependency of pods, hay and biological yields, in general, increased significantly by $29.70,36.89$ and 45.87 ; 15.08, 21.02 and 26.93; and 20.76, 27.18 and $34.28 \%$, respectively with inoculation with VAM, BR and VAM+BR as illustrate in Table 4. Shibata and Yano (2003) found that, inoculation with VAM greatly increased $P$ uptake in pigeonpeas and peanuts more than in soybeans, indicating greater mycorrhizal dependency in both these plants. Also, Elhindi et al. (2017) found that the sweet basil plants appeared to have high dependency on AMF which improved plant growth, photosynthetic efficiency, gas exchange and water use efficiency under salinity stress.

Results in Table (4) observed that kernel and hay nitrogen, phosphorus and potassium concentrations were much higher in the inoculated plants than uninoculated. The VAM+BR and BR treatments recorded significantly highest kernel nitrogen content (3.54 and 3.45\%) which increases by $34.09 \%$ and $30.68 \%$ compared with uninoculated treatment. In the same time, VAM+BR and BR treatments recorded highly hay nitrogen content (3.05 and 2.95\%) with increase of 43.86 and $39.15 \%$ compared to uninoculated treatment. Bagayoko et al. (2000) reported that $P$ application could led to large increase in early root growth severely $P$ deficient soils, following prerequisite for early mycorrhizal colonization and a subsequent significant contribution of $A M$ to increase plant growth and nitrogen uptake. On the other hand, Govindarajulu et al. (2005) found that the VAM fungi are able to provide enough $\mathbf{N}$ for optimal plant growth and development knowing that inorganic $\mathrm{N}$ taken up by the fungi can be incorporated into amino acids that are further transferred to the plant.
Also, it is clear in Table 4 that the highest nitrogen content in hay (3.34\%) was observed in with-Mo treatment under bradyrhizobium inoculation. That's indicate the role of molybdenum to enhance nitrogen fixation process. Data also reveal higher $N, P$ and $K$ concentration in the single inoculation of VAM and/or BR under the mineral fertilizers when compared with uninoculated treatments. It is of interest to mention that two inoculants enhance other to fix nitrogen and solubilize $P$, this was proved from the highly significant data of $\mathrm{N}$ and $\mathrm{P}$ content in kernel and hay. The increased efficiency of mycorrhizal plants versus non-mycorrhizal is caused by the active uptake and transport of nutrients by mycorrhizae. Antunes et al. (2006) and Javaid (2010) stated that, in Mediterranean soils with high phosphate fixing capacity, $\mathrm{N}$ fixation by rhizobia is weak due to limited supply of phosphorus and other minor nutrients. The AM fungi are commonly associated with legumes in these soils and, therefore, can increase plant nutrient uptake. The nitrogen percentage in peanut plants was lower in bradyrhizobium only inoculated plants than that in co-inoculated plants. Nodules on co-inoculated peanut roots fixed more nitrogen compared with the nodules on bradyrhizobium only inoculated roots (Zhang et al., 2016). Protein content in peanut kernel and hay was significantly higher over control when the plants were inoculated with VAM and Bradyrhizobium or combination of them (Table 4). The maximum protein percentage (21.77 and 27.83\%) for kernel and hay was obtained from the VAM+BR treatment followed by BR and VAM where protein percentage (20.67 and 19.30) for kernel and (18.35 and 17.00) for hay, respectively. The maximum protein percentage was noticed in N3 ( $120 \%$ of recommended nitrogen dose) followed by N2 (100\% of recommended 
Table (4): Nitrogen, Phosphorus and Potassium content (\%) of dry leaves of peanut plants, inoculated with VA mycorrhizal Fungi and lor Bradyrhizobium, grown in soil amended with either nitrogen, phosphorus or molybdenum fertilizers

\begin{tabular}{|c|c|c|c|c|c|c|c|c|c|}
\hline \multicolumn{2}{|c|}{ Fertilizers } & \multicolumn{3}{|c|}{ Kernel } & \multicolumn{3}{|c|}{ Hay } & \multirow{2}{*}{$\begin{array}{c}\text { kernel } \\
\text { protein } \\
\text { (\%) }\end{array}$} & \multirow{2}{*}{$\begin{array}{c}\text { hay } \\
\text { protein } \\
\text { (\%) }\end{array}$} \\
\hline Mineral & Bio & $\mathbf{N}$ & $\mathbf{P}$ & $\mathrm{K}$ & $\mathbf{N}$ & $\mathbf{P}$ & $\mathrm{K}$ & & \\
\hline \multirow{5}{*}{ N1 } & Un-Inoc. & 2.44 & 0.30 & 1.81 & 2.10 & 0.34 & 1.62 & 15.25 & 13.13 \\
\hline & VAM & 3.06 & 0.36 & 1.95 & 2.61 & 0.42 & 1.75 & 19.13 & 16.31 \\
\hline & BR & 3.54 & 0.32 & 1.90 & 3.04 & 0.38 & 1.70 & 22.13 & 19.00 \\
\hline & VAM+BR & 3.70 & 0.37 & 2.21 & 3.17 & 0.49 & 1.90 & 23.13 & 19.81 \\
\hline & Mean & 3.19 & 0.34 & 1.97 & 2.73 & 0.41 & 1.74 & 19.91 & 17.06 \\
\hline \multirow{5}{*}{ N2 } & Un-Inoc. & 2.86 & 0.28 & 1.84 & 2.43 & 0.30 & 1.64 & 17.88 & 15.19 \\
\hline & VAM & 3.24 & 0.37 & 1.97 & 2.77 & 0.41 & 1.81 & 20.25 & 17.31 \\
\hline & BR & 3.60 & 0.33 & 1.92 & 3.08 & 0.37 & 1.77 & 22.50 & 19.25 \\
\hline & VAM+BR & 3.78 & 0.38 & 2.15 & 3.25 & 0.50 & 1.92 & 23.63 & 20.31 \\
\hline & Mean & 3.37 & 0.34 & 1.97 & 2.88 & 0.40 & 1.79 & 21.06 & 18.02 \\
\hline \multirow{5}{*}{ N3 } & Un-Inoc. & 3.04 & 0.32 & 1.86 & 2.64 & 0.30 & 1.62 & 19.00 & 16.50 \\
\hline & VAM & 3.26 & 0.38 & 2.00 & 2.79 & 0.43 & 1.79 & 20.38 & 17.44 \\
\hline & BR & 3.64 & 0.34 & 1.94 & 3.12 & 0.41 & 1.76 & 22.75 & 19.50 \\
\hline & VAM+BR & 3.66 & 0.39 & 2.19 & 3.14 & 0.50 & 1.92 & 22.88 & 19.63 \\
\hline & Mean & 3.40 & 0.36 & 2.00 & 2.92 & 0.41 & 1.77 & 21.25 & 18.27 \\
\hline \multicolumn{2}{|c|}{ Mean } & 3.32 & 0.35 & 1.98 & 2.85 & 0.40 & 1.77 & 20.74 & 17.78 \\
\hline \multirow{5}{*}{ P1 } & Un-Inoc. & 2.84 & 0.22 & 1.76 & 1.89 & 0.18 & 1.62 & 17.75 & 11.81 \\
\hline & VAM & 3.11 & 0.38 & 1.89 & 2.33 & 0.53 & 1.78 & 19.44 & 14.56 \\
\hline & BR & 3.50 & 0.31 & 1.85 & 2.71 & 0.40 & 1.68 & 21.88 & 16.94 \\
\hline & VAM+BR & 3.64 & 0.41 & 2.17 & 2.83 & 0.55 & 1.88 & 22.75 & 17.69 \\
\hline & Mean & 3.27 & 0.33 & 1.92 & 2.44 & 0.42 & 1.74 & 20.45 & 15.25 \\
\hline \multirow{5}{*}{ P2 } & Un-Inoc. & 2.74 & 0.24 & 1.79 & 1.93 & 0.22 & 1.67 & 17.13 & 12.06 \\
\hline & VAM & 3.05 & 0.39 & 1.92 & 2.36 & 0.54 & 1.84 & 19.06 & 14.75 \\
\hline & BR & 3.44 & 0.33 & 1.94 & 2.71 & 0.41 & 1.79 & 21.50 & 16.94 \\
\hline & VAM+BR & 3.51 & 0.42 & 2.11 & 2.82 & 0.56 & 1.92 & 21.94 & 17.63 \\
\hline & Mean & 3.19 & 0.35 & 1.94 & 2.46 & 0.43 & 1.81 & 19.91 & 15.34 \\
\hline \multirow{5}{*}{ P3 } & Un-Inoc. & 2.70 & 0.36 & 1.82 & 1.95 & 0.26 & 1.64 & 16.88 & 12.19 \\
\hline & VAM & 2.96 & 0.41 & 2.01 & 2.38 & 0.54 & 1.85 & 18.50 & 14.88 \\
\hline & BR & 3.32 & 0.37 & 1.95 & 2.77 & 0.41 & 1.83 & 20.75 & 17.31 \\
\hline & VAM+BR & 3.40 & 0.43 & 2.19 & 2.86 & 0.58 & 1.91 & 21.25 & 17.88 \\
\hline & Mean & 3.10 & 0.39 & 1.99 & 2.49 & 0.45 & 1.81 & 19.34 & 15.56 \\
\hline \multicolumn{2}{|c|}{ Mean } & 3.18 & 0.36 & 1.95 & 2.46 & 0.43 & 1.78 & 19.90 & 15.39 \\
\hline \multirow{5}{*}{$\begin{array}{c}\text { without } \\
\text { Mo }\end{array}$} & Un-Inoc. & 2.21 & 0.29 & 1.59 & 2.04 & 0.33 & 1.58 & 13.81 & 12.75 \\
\hline & VAM & 2.78 & 0.35 & 1.71 & 2.52 & 0.40 & 1.66 & 17.38 & 15.75 \\
\hline & BR & 3.11 & 0.33 & 1.68 & 2.94 & 0.37 & 1.65 & 19.44 & 18.38 \\
\hline & VAM+BR & 3.20 & 0.36 & 1.94 & 3.05 & 0.47 & 1.68 & 20.00 & 19.06 \\
\hline & Mean & 2.83 & 0.33 & 1.73 & 2.64 & 0.39 & 1.64 & 17.66 & 16.48 \\
\hline \multirow{5}{*}{ with Mo } & Un-Inoc. & 2.32 & 0.28 & 1.66 & 2.00 & 0.31 & 1.60 & 14.50 & 12.50 \\
\hline & VAM & 2.87 & 0.33 & 1.73 & 2.55 & 0.49 & 1.67 & 17.94 & 15.94 \\
\hline & BR & 3.46 & 0.33 & 1.72 & 3.21 & 0.35 & 1.66 & 21.63 & 20.06 \\
\hline & VAM+BR & 3.47 & 0.34 & 1.93 & 3.34 & 0.52 & 1.69 & 21.69 & 20.88 \\
\hline & Mean & 3.03 & 0.32 & 1.76 & 2.78 & 0.42 & 1.66 & 18.94 & 17.34 \\
\hline \multicolumn{2}{|c|}{ Mean } & 3.01 & 0.34 & 1.81 & 2.62 & 0.41 & 1.69 & 18.83 & 16.40 \\
\hline \multirow{2}{*}{$\operatorname{LSD}_{0.05}$} & Mineral & 0.012 & 0.001 & 0.007 & 0.01 & 0.001 & 0.006 & 0.076 & 0.066 \\
\hline & Bio & 0.009 & 0.001 & 0.005 & 0.007 & 0.001 & 0.004 & 0.054 & 0.047 \\
\hline
\end{tabular}


dose) fertilizer mineral treatment. Fries et al. (1998) documented similar findings. Moreover, Elsheikh and Mohamedzein (1998) reported that Bradyrhizobium with nitrogen fertilizers significantly increased protein content in groundnut seed. The relationship between NPK uptake and protein content (\%) was linearly and positively correlated to colonization. Minerdi et al. (2001) and Badawi et al. (2011) stated that bacterialAM fungal-legume tripartite symbiosis showed better nitrogen fixation (nodule number, nitrogen and protein contents as well as nitrogenase activities) in peanut plants than that of bacterial-legume symbiosis.

\section{Nitrogen and phosphorus use} efficiencies:

Nitrogen use efficiency (NUE), nitrogen utilization efficiency (NUTE) and grain nitrogen accumulation efficiency (GNAE) has the highest values under inoculation with VAM+BR followed by BR then VAM treatments when compared to uninoculated treatments (Table 5). Totally NUE increased by $25.80,23.22$ and $21.67 \%$ for $V A M+B R$, BR and VAM, respectively when compared with uninoculated treatment. While totally NUTE increased by 42.31, 24.13 and $4.87 \%$ for $V A M+B R, B R$ and VAM, respectively when compared with uninoculated treatment. Whereas, totally GNAE increased by $72.5,62.5$ and $42.5 \%$ compared to uninoculated treatment. For different treatments, NUE and GNAE was significantly high in N1 and N2 mineral fertilizer treatments. Increasing plant $\mathrm{N}$ uptake efficiency can reduce the consumption of $\mathrm{N}$ fertilizers, and is of great significance for development of sustainable agriculture. Although the contribution of VAM fungi to plant $N$ nutrition varies widely in diverse symbiotic systems, VAM fungi can transfer substantial amounts of $\mathrm{N}$ to their hosts (Chen et al., 2018).

\section{CONCLUSION}

The data of this study concluded that the dual application of Bradyrhizobium and AMF was more effective than single inoculation. Inoculation with VAM and/or $B R$ can, synergistically, remove the deficient effect of $N$ and $P$ in the soil of low nutrient content. This could be important to enhance the production of peanut plants cultivated in sandy soils and therefore improve the fitness of plants. Development of such a sustainable biofertilizers technology for maximum and environmentally friendly crop production and preserve soil sustainability is highly desirable. 
Table (5): Nitrogen and Phosphorus Use Efficiencies of peanut, inoculated with VA mycorrhizal Fungi and lor Bradyrhizobium, grown in soil amended with either nitrogen, phosphorus or molybdenum fertilizers

\begin{tabular}{|c|c|c|c|c|c|c|c|c|c|}
\hline \multicolumn{2}{|c|}{ Fertilizers } & $\begin{array}{l}\text { Total N- } \\
\text { Applied }\end{array}$ & NUE & NUTE & GNAE & \multirow{2}{*}{$\begin{array}{l}\text { Total P- } \\
\text { Applied } \\
\mathrm{Kg} \mathrm{ha}^{-1}\end{array}$} & PUE & PUTE & GPAE \\
\hline Mineral & Bio & $\mathrm{Kg} \mathrm{ha}^{-1}$ & \multicolumn{3}{|c|}{$\mathrm{kg} \mathrm{kg}^{-1}$} & & \multicolumn{3}{|c|}{$\mathrm{kg} \mathrm{kg}^{-1}$} \\
\hline \multirow{5}{*}{ N1 } & Un-Inoc. & 53.55 & 26.35 & 13.94 & 0.64 & 71.4 & 19.76 & 93.81 & 0.06 \\
\hline & VAM & 53.55 & 31.63 & 11.20 & 0.97 & 71.4 & 23.73 & 76.68 & 0.09 \\
\hline & BR & 53.55 & 31.52 & 9.31 & 1.12 & 71.4 & 23.64 & 81.95 & 0.08 \\
\hline & VAM+BR & 53.55 & 32.06 & 8.75 & 1.19 & 71.4 & 24.05 & 63.91 & 0.09 \\
\hline & Mean & 53.55 & 30.39 & 10.80 & 0.98 & 71.40 & 22.79 & 79.09 & 0.08 \\
\hline \multirow{5}{*}{ N2 } & Un-Inoc. & 80.44 & 17.73 & 11.53 & 0.51 & 71.4 & 19.97 & 100.24 & 0.06 \\
\hline & VAM & 80.44 & 22.07 & 10.71 & 0.71 & 71.4 & 24.86 & 78.60 & 0.09 \\
\hline & BR & 80.44 & 22.33 & 9.32 & 0.80 & 71.4 & 25.15 & 84.32 & 0.08 \\
\hline & VAM+BR & 80.44 & 22.50 & 8.68 & 0.85 & 71.4 & 25.35 & 63.68 & 0.10 \\
\hline & Mean & 80.44 & 21.16 & 10.06 & 0.72 & 71.40 & 23.83 & 81.71 & 0.08 \\
\hline \multirow{5}{*}{ N3 } & Un-Inoc. & 107.1 & 13.73 & 10.58 & 0.42 & 71.4 & 20.60 & 95.38 & 0.07 \\
\hline & VAM & 107.1 & 16.54 & 10.46 & 0.54 & 71.4 & 24.80 & 73.98 & 0.09 \\
\hline & BR & 107.1 & 17.04 & 9.20 & 0.62 & 71.4 & 25.56 & 77.47 & 0.09 \\
\hline & VAM+BR & 107.1 & 17.46 & 9.04 & 0.64 & 71.4 & 26.19 & 63.76 & 0.10 \\
\hline & Mean & 107.10 & 16.19 & 9.82 & 0.55 & 71.40 & 24.29 & 77.65 & 0.09 \\
\hline \multicolumn{2}{|c|}{ Mean } & 80.36 & 22.58 & 10.23 & 0.75 & 71.40 & 23.64 & 79.48 & 0.08 \\
\hline \multirow{5}{*}{ P1 } & Un-Inoc. & 107.1 & 13.16 & 13.97 & 0.37 & 35.7 & 39.47 & 158.45 & 0.09 \\
\hline & VAM & 107.1 & 16.45 & 12.44 & 0.51 & 35.7 & 49.36 & 66.62 & 0.19 \\
\hline & BR & 107.1 & 16.35 & 10.50 & 0.57 & 35.7 & 49.05 & 83.40 & 0.15 \\
\hline & VAM+BR & 107.1 & 16.59 & 9.84 & 0.60 & 35.7 & 49.78 & 59.63 & 0.20 \\
\hline & Mean & 107.10 & 15.64 & 11.69 & 0.52 & 35.70 & 46.91 & 92.02 & 0.16 \\
\hline \multirow{5}{*}{ P2 } & Un-Inoc. & 107.1 & 13.38 & 13.65 & 0.37 & 53.55 & 26.76 & 131.10 & 0.06 \\
\hline & VAM & 107.1 & 16.66 & 12.26 & 0.51 & 53.55 & 33.31 & 64.19 & 0.13 \\
\hline & BR & 107.1 & 16.44 & 10.33 & 0.57 & 53.55 & 32.89 & 78.52 & 0.11 \\
\hline & VAM+BR & 107.1 & 17.33 & 9.97 & 0.61 & 53.55 & 34.66 & 58.33 & 0.15 \\
\hline & Mean & 107.10 & 15.95 & 11.56 & 0.51 & 53.55 & 31.90 & 83.04 & 0.11 \\
\hline \multirow{5}{*}{ P3 } & Un-Inoc. & 107.1 & 13.35 & 13.30 & 0.36 & 71.4 & 20.03 & 99.76 & 0.07 \\
\hline & VAM & 107.1 & 16.94 & 12.17 & 0.50 & 71.4 & 25.41 & 62.39 & 0.10 \\
\hline & BR & 107.1 & 16.44 & 10.14 & 0.55 & 71.4 & 24.66 & 74.76 & 0.09 \\
\hline & VAM+BR & 107.1 & 17.49 & 9.81 & 0.59 & 71.4 & 26.23 & 55.35 & 0.11 \\
\hline & Mean & 107.10 & 16.06 & 11.36 & 0.50 & 71.40 & 24.08 & 73.07 & 0.10 \\
\hline \multicolumn{2}{|c|}{ Mean } & 107.10 & 15.88 & 11.53 & 0.51 & 53.55 & 34.30 & 82.71 & 0.12 \\
\hline \multirow{5}{*}{$\begin{array}{c}\text { without } \\
\text { Mo }\end{array}$} & Un-Inoc. & 107.1 & 13.07 & 14.62 & 0.29 & 71.4 & 19.61 & 96.22 & 0.06 \\
\hline & VAM & 107.1 & 14.79 & 11.31 & 0.41 & 71.4 & 22.18 & 76.24 & 0.08 \\
\hline & BR & 107.1 & 15.01 & 9.60 & 0.47 & 71.4 & 22.52 & 79.99 & 0.07 \\
\hline & VAM+BR & 107.1 & 15.80 & 9.31 & 0.51 & 71.4 & 23.70 & 65.67 & 0.09 \\
\hline & Mean & 107.10 & 14.67 & 11.21 & 0.42 & 71.40 & 22.00 & 79.53 & 0.07 \\
\hline \multirow{5}{*}{$\begin{array}{l}\text { with } \\
\text { Mo }\end{array}$} & Un-Inoc. & 107.1 & 13.31 & 13.64 & 0.31 & 71.4 & 19.96 & 94.60 & 0.06 \\
\hline & VAM & 107.1 & 15.85 & 11.26 & 0.46 & 71.4 & 23.78 & 67.35 & 0.08 \\
\hline & BR & 107.1 & 16.70 & 9.05 & 0.58 & 71.4 & 25.06 & 86.36 & 0.08 \\
\hline & VAM+BR & 107.1 & 16.77 & 8.57 & 0.58 & 71.4 & 25.15 & 61.88 & 0.09 \\
\hline & Mean & 107.10 & 15.66 & 10.63 & 0.48 & 71.40 & 23.49 & 77.55 & 0.08 \\
\hline \multicolumn{2}{|c|}{ Mean } & 107.10 & 15.40 & 11.12 & 0.47 & 65.45 & 26.60 & 79.93 & 0.09 \\
\hline \multirow[t]{2}{*}{$\operatorname{LSD}_{0.05}$} & Mineral & ---- & 0.095 & 0.037 & 0.003 & ---- & 0.095 & 0.299 & 0.003 \\
\hline & Bio & ---- & 0.067 & 0.026 & 0.002 & $-\cdots$ & 0.067 & 0.211 & 0.002 \\
\hline
\end{tabular}




\section{REFERENCES}

Abd-Alla M.H. (2011) Nodulation and nitrogen fixation in interspecies grafts of soybean and common bean is controlled by isoflavonoid signal molecules translocated from shoot. Plant Soil Environ 57:453-458.

Abiala M., O. Popoola, O. Olawuyi, J. Oyelude, A. Akanmu, A. Killani, O. Osonubi and A. Odebode. (2013) Harnessing the potentials of Vesicular Arbuscular Mycorrhizal (VAM) fungi to plant growth-a review. International Journal of Pure Applied Sciences Technology 14:61.

Alloush G., S. Zeto and R. Clark. (2000) Phosphorus source, organic matter, and arbuscular mycorrhiza effects on growth and mineral acquisition of chickpea grown in acidic soil. Journal of plant nutrition 23:1351-1369.

Antoun H., C.J. Beauchamp, N. Goussard, R. Chabot and R. Lalande. (1998) Potential of Rhizobium and Bradyrhizobium species as plant growth promoting rhizobacteria on non-legumes: effect on radishes (Raphanus sativus L.), Molecular microbial ecology of the soil, Springer. pp. 57-67.

Antoun H. and D. Prévost. (2005) Ecology of plant growth promoting rhizobacteria, PGPR: Biocontrol and biofertilization, Springer. pp. 1-38.

Antunes P.M., A. De Varennes, I. Rajcan and M.J. Goss. (2006) Accumulation of specific flavonoids in soybean (Glycine max (L.) Merr.) as a function of the early tripartite symbiosis with arbuscular mycorrhizal fungi and Bradyrhizobium japonicum (Kirchner) Jordan. Soil Biology Biochemistry 38:1234-1242.

ARM S. (2014) Influence of arbusclar mycorrhiza in presence of Rhizobium, nitrogen and phosphorus on growth and yield of mungbean. Bulletin of the Institute of Tropical Agriculture, Kyushu University 37:1-26.
Badawi F.S.F., A.M.M. Biomy and A.H. Desoky. (2011) Peanut plant growth and yield as influenced by coinoculation with Bradyrhizobium and some rhizo-microorganisms under sandy loam soil conditions. Annals of Agricultural Sciences 56:17-25. DOI: https://doi.org/10.1016/j.aoas.2011.05. 005.

Bagayoko M., E. George, V. Römheld and A. Buerkert. (2000) Effects of mycorrhizae and phosphorus on growth and nutrient uptake of millet, cowpea and sorghum on a West African soil. The journal of agricultural science 135:399-407.

Bremner J.M. and C. Mulvaney. (1982) Nitrogen-Total 1, Methods of soil analysis. Part 2. Chemical microbiological properties. pp. 595624.

Breuillin-Sessoms F., D.S. Floss, S.K. Gomez, N. Pumplin, Y. Ding, V. Levesque-Tremblay, R.D. Noar, D.A. Daniels, A. Bravo and J.B. Eaglesham. (2015) Suppression of arbuscule degeneration in Medicago truncatula phosphate transporter4 mutants is dependent on the ammonium transporter 2 family protein AMT2; 3. The Plant Cell:tpc. 114.131144.

Bücking H. and A. Kafle. (2015) Role of arbuscular mycorrhizal fungi in the nitrogen uptake of plants: current knowledge and research gaps. Agronomy 5:587-612.

Bulgarelli R.G., F.C.C. Marcos, R.V. Ribeiro and S.A.L. de Andrade. (2017) Mycorrhizae enhance nitrogen fixation and photosynthesis in phosphorusstarved soybean (Glycine max $L$. Merrill). Environmental and Experimental Botany 140:26-33. DOI: https://doi.org/10.1016/j.envexpbot.201 7.05.015.

Chang C., F. Nasir, L. Ma and C. Tian. (2017) Molecular communication and nutrient transfer of arbuscular 
mycorrhizal fungi, symbiotic nitrogenfixing bacteria, and host plant in tripartite symbiosis, Legume Nitrogen Fixation in Soils with Low Phosphorus Availability, Springer. pp. 169-183.

Chen A., M. Gu, S. Wang, J. Chen and G. Xu. (2018) Transport properties and regulatory roles of nitrogen in arbuscular mycorrhizal symbiosis. Seminars in Cell \& Developmental Biology 74:80-88. DOI: https://doi.org/10.1016/j.semcdb.2017. 06.015 .

Cottenie A., M. Verloo, L. Kiekens, G. Velghe and R. Camerlynik. (1982) Chemical analysis of plant on soils lab. Anal. Agroch. Fac. Agric. State University Gent., Belgium 63.

El-Azouni I.M., Y. Hussein and L.D. Shaaban. (2008) The associative effect of VA mycorrhizae with Bradyrhizobium as biofertilizers on growth and nutrient uptake of Arachis hypogaea. Res J Agric Biol Sci 4:187197.

Elhindi K.M., A.S. El-Din and A.M. Elgorban. (2017) The impact of arbuscular mycorrhizal fungi in mitigating salt-induced adverse effects in sweet basil (Ocimum basilicum L.). Saudi J Biol Sci 24:170-179. DOI: 10.1016/j.sjbs.2016.02.010.

Elsheikh E.A. and E. Mohamedzein. (1998) Effect of Bradyrhizobium, VA mycorrhiza and fertilisers on seed composition of groundnut. Annals of applied biology. 132:325-330.

Fageria N.K., V.C. Baligar and C.A. Jones. (1997) Growth and mineral nutrition of field crops CRC Press.

Fries L.L., R.S. Pacovsky, G.R. Safir and J. Kaminski. (1998) Phosphorus effect on phosphatase activity in endomycorrhizal maize. Physiologia Plantarum 103:162-171.

Gee G.W. and J.W. Bauder. (1986) Particlesize analysis. Methods of soil analysis Part 2. Agron. Monogr. 9. ASA and SSSA, Madison, WI.
Giovannetti M. and B. Mosse. (1980) An evaluation of techniques for measuring vesicular arbuscular mycorrhizal infection in roots. New phytologist 84:489-500.

Gomez K.A., K.A. Gomez and A.A. Gomez. (1984) Statistical procedures for agricultural research John Wiley \& Sons.

Govindarajulu M., P.E. Pfeffer, H. Jin, J. Abubaker, D.D. Douds, J.W. Allen, H. Bücking, P.J. Lammers and Y. Shachar-Hill. (2005) Nitrogen transfer in the arbuscular mycorrhizal symbiosis. Nature 435:819.

Guo Y., Y. Ni and J. Huang. (2010) Effects of rhizobium, arbuscular mycorrhiza and lime on nodulation, growth and nutrient uptake of lucerne in acid purplish soil in China. Tropical Grasslands 44:109-114.

Huggins D. and W. Pan. (2003) Key indicators for assessing nitrogen use efficiency in cereal-based agroecosystems. Journal of crop production 8:157-185.

Hunter A. (1984) Soil fertility analytical services in Bangladesh. Consultancy Report BARC, Dhaka.

Jackson, M.L., 1970. Soil Chemical Analysis. Prentice Hall, Englewood Ceiffs, N. J.

Jackson R. and P. Mason. (1984) Mycorrhiza. , ISBN 0-7131-2876-3, Edward Arnold, London, p 60.

Javaid A. (2010) Role of arbuscular mycorrhizal fungi in nitrogen fixation in legumes, Microbes for Legume Improvement, Springer. pp. 409-426.

Kaya C., M. Ashraf, O. Sonmez, S. Aydemir, A.L. Tuna and M.A. Cullu. (2009) The influence of arbuscular mycorrhizal colonisation on key growth parameters and fruit yield of pepper plants grown at high salinity. Scientia Horticulturae 121:1-6.

Khanam D., M. Mridha and A. Solaiman. (2005) Effect of dual inoculation of arbuscular mycorrhiza and Rhizobium 
on root colonization and spore population in chickpea. Bangladesh $\mathbf{J}$. Microbiol 22:15-18.

Knudsen D., G. Peterson and P. Pratt. (1982) Lithium, Sodium, and Potassium, Methods of soil analysis. Part 2. Chemical and microbiological properties. pp. 225-246. Agron. Monogr. 9. ASA and SSSA, Madison, WI.

Kobae Y., Y. Ohmori, C. Saito, K. Yano, R. Ohtomo and T. Fujiwara. (2016) Phosphate treatment strongly inhibits new arbuscule development but not the maintenance of arbuscule in mycorrhizal rice roots. Plant physiology:pp. 00127.02016.

Mahrous N.M., S.A. Safina, H.H.A. Taleb and S.M.E.-S. El-Behlak. (2015) Integrated use of organic, inorganic and bio fertilizers on yield and quality of two peanut (Arachis hypogaea L.) cultivars grown in a sandy saline soil. J American-Eurasian Journal of Agricultural Environmental Sciences 15:1067-1074.

Malligawad L.H. (2010) Effect of organics on the productivity of groundnut and its residual effects on succeeding safflower under rainfed farming situations, $19^{\text {th }}$ World Congress of Soil Science, Soil Solutions for a Changing World.-Brisbane, Australia.

Meding S. and R. Zasoski. (2008) Hyphalmediated transfer of nitrate, arsenic, cesium, rubidium, and strontium between arbuscular mycorrhizal forbs and grasses from a California oak woodland. Soil Biology Biochemistry 40:126-134.

Minerdi D., R. Fani, R. Gallo, A. Boarino and P. Bonfante. (2001) Nitrogen fixation genes in an endosymbioticBurkholderia strain. Applied environmental microbiology 67:725-732.

Mirdhe R.M. and H. Lakshman. (2009) Synergistic effect of arbuscular mycorrhizal fungi and Rhizobium inoculation on dalbergia sissoo roxb in unsterile soil. Nat. Environ. Pollut. Technol 8:781-784.

Mwenda G.M., N. Karanja, H. Boga, J. Kahindi, A. Muigai and D. Odee. (2010) Abundance and diversity of legume nodulating Rhizobia in soils of Embu district, Kenya. Tropical Subtropical Agroecosystems 13:1-10.

Mylona P., K. Pawlowski and T. Bisseling. (1995) Symbiotic nitrogen fixation. The Plant Cell 7:869.

Nelson D. and L.E. Sommers. (1982) Total carbon, Organic Carbon, and Organic Matter 1, Methods of soil analysis. Part 2. Chemical microbiological properties. pp. 539-579.

Nouri E., F. Breuillin-Sessoms, U. Feller and D. Reinhardt. (2014) Phosphorus and nitrogen regulate arbuscular mycorrhizal symbiosis in Petunia hybrida. PLoS One 9:e90841.

Öhlinger R. (1996) Phosphomonoesterase activity with the substrate phenylphosphate,[In:] F. Schinner, R. Öhlinger, E. Kandeler, R. Margesin (Eds.), Methods in soil biology, Springer, Berlin.

Olsen S. and L. Sommers. (1982) Phosphorus. p. 403-430. AL Page et al.(ed.) Methods of soil analysis. Part 2. Agron. Monogr. 9. ASA and SSSA, Madison, WI.

Ossler J.N., C.A. Zielinski and K.D. Heath. (2015) Tripartite mutualism: Facilitation or trade-offs between rhizobial and mycorrhizal symbionts of legume hosts. American journal of botany 102:1332-1341.

Page A., R. Miller and D. Keeney. (1982) Methods of Soil Analysis. Part 2. Agron. Monogr. 9. ASA and SSSA, Madison, WI.

Phillips J.M. and D. Hayman. (1970) Improved procedures for clearing roots and staining parasitic and vesicular-arbuscular mycorrhizal fungi for rapid assessment of infection. $J$ 
Transactions of the British mycological Society 55:158-161.

Sharda J. and R. Koide. (2010) Exploring the role of root anatomy in P-mediated control of colonization by arbuscular mycorrhizal fungi. Botany 88:165-173.

Sheng M., M. Tang, H. Chen, B. Yang, F. Zhang and Y. Huang. (2009) Influence of arbuscular mycorrhizae on the root system of maize plants under salt stress. Canadian journal of microbiology 55:879-886.

Shibata R. and K. Yano. (2003) Phosphorus acquisition from nonlabile sources in peanut and pigeonpea with mycorrhizal interaction. Applied Soil Ecology 24:133-141. DOI: https://doi.org/10.1016/S09291393(03)00093-3.

Shokri S. and B. Maadi. (2009) Effects of arbuscular mycorrhizal fungus on the mineral nutrition and yield of Trifolium alexandrinum plants under salinity stress. J Agron 8:79-83.

Smith S. and D. Read. (2008) Mycorrhizal Symbiosis 3rd edn Academic Press: San Diego, CA, USA.

Solaiman A., M. Rabbani and M. Molla. (2005) Effects of inoculation of Rhizobium and Arbuscular Mycorrhiza, Poultry litter, Nitrogen, and Phosphorus on growth and yield in chickpea. Korean Journal of Crop Science 50:256-261.

Tabassum Y., B. Tanvir and H. Farrukh. (2012) Effect of arbuscular mycorrhizal inoculation on nutrient uptake, growth and productivity of chickpea (Cicer arietinum) varieties. International journal of agronomy plant production 3:334-345.

Tavasolee A., N. Aliasgharzad, G. SalehiJouzani, M. Mardi and A. Asgharzadeh. (2011) Interactive effects of arbuscular mycorrhizal fungi and rhizobial strains on chickpea growth and nutrient content in plant. African Journal of Biotechnology 10:75857591.

Willis A., B. Rodrigues and P. Harris. (2013) The ecology of arbuscular mycorrhizal fungi. Critical Reviews in Plant Sciences 32:1-20.

Wu Q., G. Li and Y. Zou. (2011) Roles of arbuscular mycorrhizal fungi on growth and nutrient acquisition of peach (Prunus persica L. Batsch) seedlings. J Anim Plant Sci 21:746-750.

Zalate P. and D. Padmani. (2009) Effect of organic manure and biofertilizers on yield, harvest index, shelling percentage and quality of kharif groundnut (Arachis hypogeae L.). International Journal of Agricultural Sciences 5:417-419.

Zhang W., H.W. Wang, X.X. Wang, X.G. Xie, M.A. Siddikee, R.S. $X u$ and C.C. Dai. (2016) Enhanced nodulation of peanut when co-inoculated with fungal endophyte Phomopsis liquidambari and bradyrhizobium. Plant Physiol Biochem 98:1-11. DOI: 10.1016/j.plaphy.2015.11.002. 
التأثير التفاعلى للبرادى رايزوبيم وفطريات الميكوريزا مع مستويات من النيتروجين والفسفور والمولبيدنيم المعدنى على الفول السودانى النامى في الاراضى الرملية

\section{نهى موسى عبد الحميا}

قسم خصوبة وميكروبيولوجيا الاراضى - مركز بحوث الصحراء - مصر الدمبر

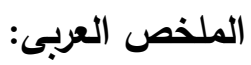

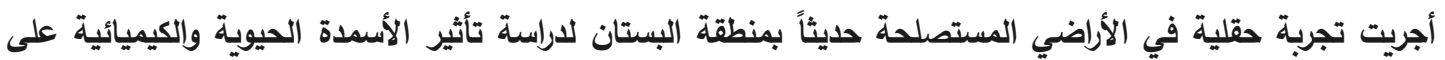

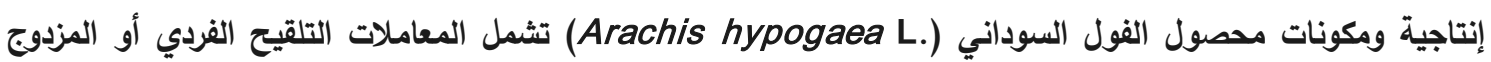

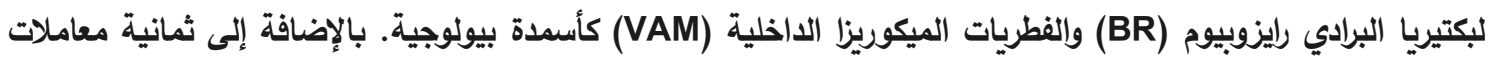

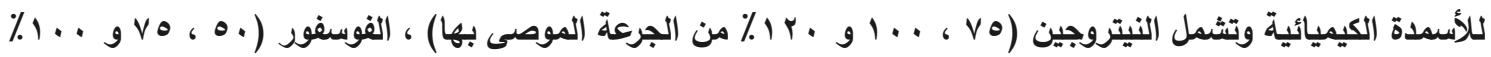

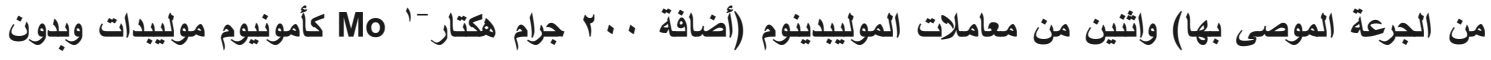

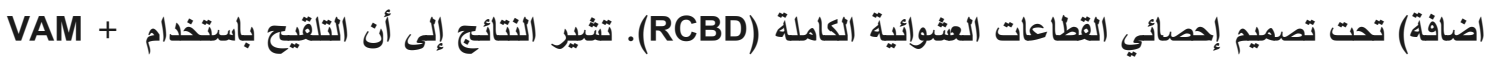

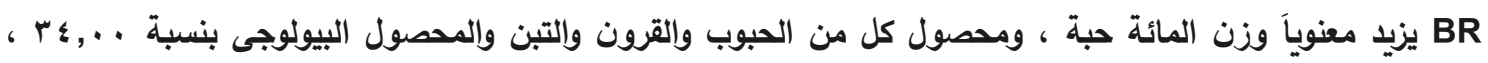

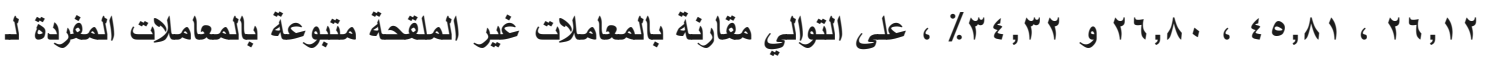

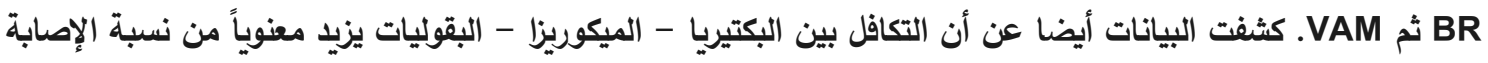

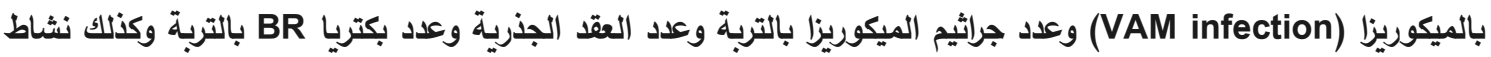

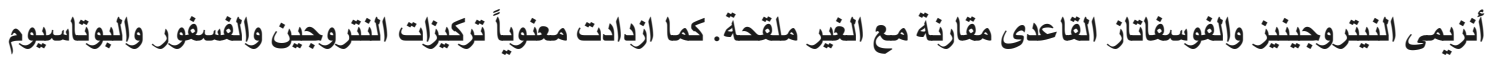

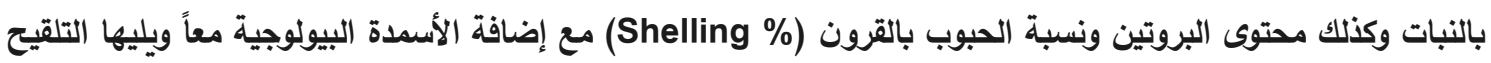

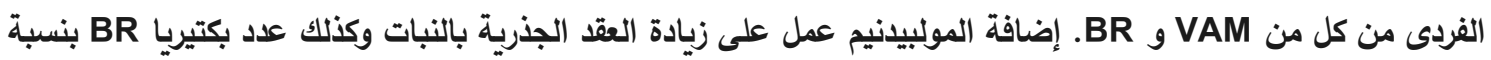

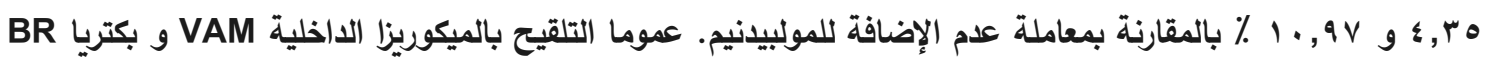

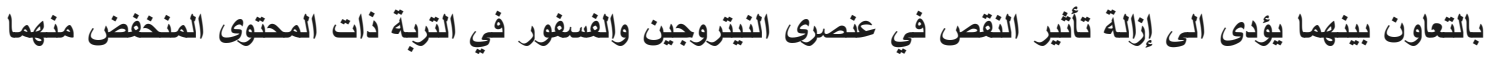

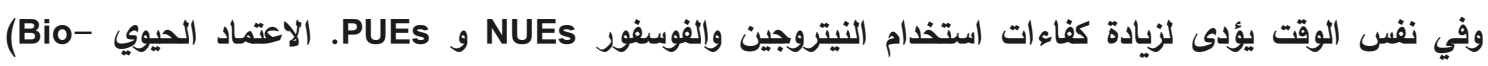

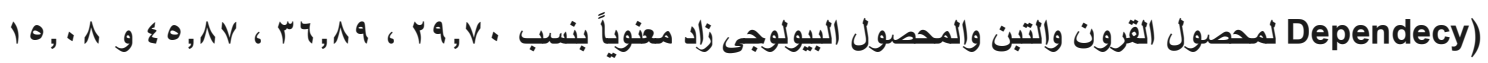

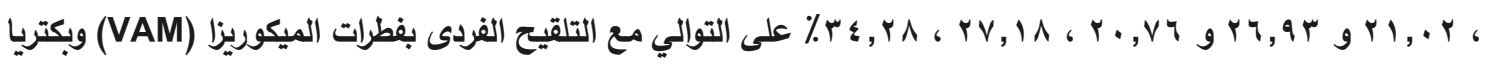

و معاً. 